УДК 343.242.4

DOI https://doi.org/10.32849/2663-5313/2020.4.46

Наталія Антонюк,

канд. юрид. наук, дочент,

дочент кафедри кримінального права і кримінологї

Львівського начіонального університету імені Івана Франка,

суддя Великої Палати Верховного Суду

\title{
ДИФЕРЕНЦІАЦІЯ КРИМІНАЛЬНОЇ ВІДПОВІДАЛЬНОСТІ У ПРАВОВИХ ІНСТИТУТАХ ЗВІЛЬНЕННЯ ВІД ПОКАРАННЯ ЧИ ЙОГО ВІДБУВАННЯ
}

Інститути звільнення від покарання та його відбування передбачають широкі повноваження судів у частині незастосування иієї форми реалізаиії кримінальної відповідальності до особи, засудженої обвинувальним вироком суду. Така судова дискреиія регламентується Кримінальним кодексом України (далі - КК). Законодавием також передбачені різні умови та підстави звільнення від покарання та його відбування. У зв'язку з иим виникає питання про диференціюючу роль иих правових інститутів. У разі позитивної відповіді на зазначене питання, постає проблема встановлення норм про ті підстави звільнення від покарання чи його відбування, за наявності яких забезпечуються можливість варіативності кримінально-правового впливу на особу.

У иьому дослідженні планується обгрунтувати значення для диференціацї̈ кримінальної відповідальності правової регламентачії звільнення від покарання та його відбування. Також ставиться за мету виявити специфіку кожної з підстав звільнення від покарання чи його відбування у контексті варіативності.

За результатами проведеної роботи встановлено, що не всі підстави звільнення від покарання чи його відбування мають значення для диферениіацї кримінальної відповідальності. Окремі з них сконструйовані законодавием таким чином, що фактично характеризують диферениіачію кримінальноправового впливу, як-от звільнення від покарання за хворобою для осіб, які стали неосудними під час відбування покарання. Також у чинному КК фактично відсутнє диферениіююче значення інститутів амністії та помилування через недостатне нормативне урегулювання останніх у КК.

Звільнення засудженого від відбування основного покарання з випробуванням зі збереженням застосування призначених судом додаткових покарань дозволяє розширити можливі варіанти застосування ивого інституту для кращої реалізаиії приниипу справедливості. Тому положення ст. 77 КК забезпечують диферениіачію кримінальної відповідальності та більш точний і персоналізований підхід у застосуванні заходів кримінальної відповідальності до особи судом.

Ключові слова: диференціююче значення, покарання, амністія, помилування, додаткове покарання.

Постановка проблеми. Варіативність кримінальної відповідальності під час її реалізації забезпечується не лише шляхом встановлення меж покарання, а й шляхом закріплення можливості звільнення від покарання чи його відбування зі збереженням негативного впливу інших форм реалізації кримінальної відповідальності. Умови і підстави для застосування звільнення від покарання чи його відбування визначені самим законодавцем. Суд застосовує відповідні норми Кримінального кодексу України (далі - КК) лише у межах, які прописані в кодексі. Ці кримінально-правові інститути не усувають самого факту засудження винного, тож $\epsilon$ всі підстави вважати їх диференціюючими.
Адже у ході їхнього застосування такі форми реалізації кримінальної відповідальності, як осуд та судимість, застосовуються до особи, а від застосування інших форм (власне покарання) вона звільняється.

Метою дослідження $є$ доведення необхідності визнавати інститути звільнення від покарання та його відбування такими, що диференціюють кримінальну відповідальність. Також варто встановити, чи всі підстави звільнення від покарання чи його відбування є такими, що диференціюють кримінальну відповідальність. Крім того, враховуючи нормативний поділ покарань на основні та додаткові, важливо з'ясувати, 
чи має диференціюючий вплив законодавче положення про можливість збереження додаткових покарань у разі звільнення від основного.

Аналіз останніх досліджень і публікацій. У юридичній літературі проблема значення інституту звільнення від покарання для диференціації кримінальної відповідальності досліджувалася у працях О. В. Васільєвского, В. К. Грищука, Л. Л. Круглікова, Т. О. Лєснієвскі-Костарєвої, Н.О.Орловської, Л. В. Павлик та М. І. Хавронюка.

Виклад основного матеріалу. На нашу думку, інститут звільнення від покарання, як і інститут звільнення від кримінальної відповідальності, має диференціююче значення. Такий підхід був підтриманий вітчизняними вченими [1, с. $148 ; 2$ с с. $42 ; 3$, с. 164]. Водночас у науковій літературі висловлюється низка тез, які навряд чи можуть бути підтримані, однак стосуються диференціюючого значення інституту звільнення від покарання.

Т. О. Лєснієвскі-Костарєва вважає звільнення від покарання індивідуалізацією кримінальної відповідальності, а от звільнення від кримінальної відповідальності - диференціацією кримінальної відповідальності [4, с. 126]. Мотивує свою позицію авторка тим, що кримінальна справа уже пройшла етап призначення покарання i наступним логічним етапом $є$ індивідуалізація кримінальної відповідальності. Тож все, що знаходиться після призначення покарання $€$ індивідуалізацією, а не диференціацією кримінальної відповідальності.

Н. А. Орловська 3 цього приводу зазначає, що з Т. О. Лєснієвскі-Костарєвою можна було би погодитися, якби не положення ч. 1, 2 ст. 105 КК, виходячи із яких поряд із покаранням специфічною формою реалізації кримінальної відповідальності є примусові заходи виховного характеру. Оскільки покарання як форма примусового кримінальноправового впливу виступає (на думку Т. О. Лєснієвскі-Костарєвої) результатом диференціації кримінальної відповідальності, то і примусові заходи виховного характеру можуть бути охарактеризовані через категорію «диференціація». Отже, звільнення від покарання із застосуванням примусових заходів виховного характеру є варіантом диференціації кримінальної відповідальності, адже йдеться про вибір однієі із двох форм реалізації останньої [3, с. 164].

Ми не вважаємо застосування примусових заходів виховного характеру однією із форм реалізації кримінальної відповідальності. Більш обгрунтовано відносити такі заходи до заходів кримінально-правового впливу як явища більш широкого, яке охо- плює собою в тому числі і кримінальну відповідальність. Погоджуємося з О. О. Дудоровим у тому, що примусові заходи виховного характеру можна визнати факультативним елементом поряд з кримінальною відповідальністю [5, с. 104].

Якщо детальніше розглянути інститут примусових заходів виховного характеру, можна простежити, що його застосування може відбуватися у разі звільнення неповнолітнього від покарання (ст. 105 КК), звільнення неповнолітнього від кримінальної відповідальності (ч. 1 ст. 97 КК) та щодо неповнолітнього, який вчинив суспільно небезпечне діяння у віці, 3 якого не може наставати кримінальна відповідальність (ч. 2 ст. 97 КК). Фактично лише у першому 3 названих випадків примусові заходи застосовуються разом із реалізацією кримінальної відповідальності. Однак таке паралельне застосування різних правових інститутів не дозволяє зробити висновок про те, що примусові заходи виховного характеру є однією із форм реалізації кримінальної відповідальності. Адже зміст таких засобів нічим не відрізняється незалежно від того, чи неповнолітнього звільняють від покарання чи взагалі застосовують їх до неповнолітнього, який не може бути суб'єктом злочину.

Інститут звільнення від покарання, як і звільнення від кримінальної відповідальності, покликаний забезпечити надання суду можливості у встановлених законодавцем рамках вибрати кілька варіантів вирішення справи для того, щоб вибрані заходи впливу були застосовані найбільш точно, індивідуалізовано. Проте ці варіанти закріплюються в законі, і суд не може виходити за їх межі, якщо закон цього не допускає. Одним із таких варіантів є застосування осуду до особи без застосування покарання. На цьому негативний вплив кримінальної відповідальності припиняється. Таким чином застосування такої форми реалізації кримінальної відповідальності, як осуд, дозволяє по-різному врегулювати правові наслідки для особи порівняно з тим, коли їі взагалі звільнять від кримінальної відповідальності і жодна з форм кримінальної відповідальності реалізована не буде. Тому ми не можемо погодитися з тим, що звільнення від покарання лежить суто у сфері індивідуалізації кримінальної відповідальності. Адже така варіативність закріплена законодавцем.

Цим аргументом можливо обгрунтувати диференціююче значення інституту звільнення від покарання загалом. Проте існування різних підстав звільнення від покарання чи його відбування потребує більш глибокого аналізу. 
У чинному КК передбачено декілька випадків звільнення особи від покарання чи його відбування. Таке широке коло заходів звільнення від покарання чи його відбування, з одного боку, забезпечує можливість належної диференціації кримінальної відповідальності за різними критеріями, а 3 іншого - створює невиправдану плутанину і деякою мірою хаос

3 проведеного О. П. Горохом дослідження випливає, що левова частка випадків звільнення від покарання припадає на застосування ст. 75 КК. У різні роки відсоткове співвідношення цього виду звільнення з іншими було 40-50\%; на другому місці - умовно-дострокове звільнення (в середньому близько 10\%); решта ж підстав застосовувалися украй рідко [6, с. 170-172]. Загалом, таке співвідношення не викликає подиву. Звільнення з випробуванням дозволяє надати шанс особі на виправлення 3 накладенням окремих обмежень і випробувального терміну. Умовно-дострокове звільнення виконує схожу роль, але у тих випадках, коли частину покарання особа уже відбула.

Інші, менш застосовні, підстави мають більш яскраво виражений диференціюючий ефект. Так, наприклад, звільнення від відбування покарання вагітних жінок і жінок, які мають дітей віком до 3 років (ст. 81 КК), враховує особливості суб'єкта злочину. Саме у зв'язку з цими особливостями суд може звільнити відповідну особу від покарання і таким чином забезпечити реакцію держави на вчинення такою особою злочину. У своїх рішеннях суди звертають увагу на те, що звільнення від покарання вагітних жінок або жінок, які мають дітей певного віку, показує, що закон ставить інтереси дитини, iї виховання вище, ніж негайне виконання покарання, вище, ніж реалізацію цілей кримінальної відповідальності, а законодавець у такий спосіб дбає про майбутнє дитини, нормальний розвиток якої може постраждати через відбування її матір'ю покарання [7; 8].

Військовослужбовці, засуджені до службового обмеження, арешту або тримання в дисциплінарному батальйоні в разі визнання їх непридатними до військової служби за станом здоров'я звільняються від покарання. Адже цей вид покарання прямо пов'язаний із проходженням військової служби. Тому втрата здатності до цієї служби автоматично призводить до втрати сенсу саме у такому покаранні.

Проте окремі із підстав звільнення від покарання чи його відбування фактично позбавлені будь-якого значення для диференціації кримінальної відповідальності.

Так, звільнення від покарання за хворобою не диференціює кримінальну відпо- відальність у тому разі, коли до особи, яка захворіла на психічну хворобу, застосовують примусові заходи медичного характеру і тому звільняють від відбування покарання. Адже неосудна особа, яка не усвідомлюе значення своїх дій та/або не може керувати ними 3 причин психічного захворювання, не повинна підлягати заходам кримінальної відповідальності нарівні з осудними. Тому принцип справедливості у цьому разі полягає не у диференціації кримінальної відповідальності, а у диференціації кримінальноправового впливу.

Вагомі застереження викликає інститут звільнення від покарання у зв'язку із амністією. Л. Л. Кругліков та О. В. Васільєвскій влучно вказують, що норма про амністію порушує загальну структуру диференціації кримінальної відповідальності; вирішення цих питань в окремому законі є несистемним, порушуються засади рівності і справедливості, баланс судової і законодавчої влади [9, с. 163].

Така диференціація кримінальної відповідальності забезпечується лише особливостями застосування звільнення від покарання до осіб, які вчинили корупційні злочини. Так, згідно з ч. 4 ст. 86 КК, якщо вирок щодо особи, яка вчинила корупційний злочин, не набрав законної сили, амністія не може бути застосована. Також може бути застосовано звільнення від покарання 3 підстав амністії та помилування до осіб, які вчинили корупційні злочини, якщо обвинувальні вироки щодо них вступили в силу (ч. 4 ст. 86 , ч. 3 ст. 87 КК) лише після фактичного відбуття ними строків покарання, передбачених для умовно-дострокового звільнення від відбування покарання (ст. 81 КК).

Однак загалом інститут амністії практично не врегульований у КК. Його застосування не має нічого спільного з принципами кримінального права. Правила амністії не обмежуються чинним кримінальним законом і передбачені окремим нормативно-правовим актом, що суперечить ч. 3 ст. 3 КК. Тому принципово важливо встановити саме у КК загальні засади, згідно з якими парламент міг би визначати коло осіб, що підлягають звільненню від покарання, коло злочинів, на які амністія не поширюється, тощо.

Більш очевидною ця проблема стає у зв'язку з реалізованими спірними фактами індивідуальної амністії [10]. Варто звернути увагу, що в переліку осіб, до яких була застосована індивідуальна амністія Законом України «Про внесення змін до Закону України “Про застосування амністії в Україні" щодо повної реабілітації політичних в'язнів», опинилися не лише політичні в’язні, а й особи, яких засудили за умисне вбивство. 
Аналогічні застереження щодо неврегульованості можна констатувати і щодо інституту помилування. Насамперед умови його застосування, категорії злочинів, групи суб'єктів мали би бути чітко прописані у КК. По-друге, оскільки помилуваними можуть бути й особи, засуджені до довічного позбавлення волі, то у КК потрібно передбачити терміни, після відбуття яких особа отримуе право звернутися про помилування. Такий крок законодавця фактично був би заходом загального характеру, який має вжити держава Україна на виконання рішення ССПЛ «Пєтухов № 2 проти України» [11]. Ми переконані, що такий термін не може бути однаковим і має бути диференційованим. Незважаючи на те, що саме покарання у вигляді довічного позбавлення волі диференціювати неможливо, можна однак провести диференціацію вчиненого засудженим злочину (злочинів). Такими диференціюючими ознаками можуть бути кількість вчинених злочинів, їх характер (об'єкт посягання, насильницький злочин чи ні, тощо), ознаки суб'єкта, ознаки співучасті, множинності. Тобто у КК мали би бути чітко зафіксовані декілька термінів, після перебігу яких різні категорії засуджених отримували би право звертатися щодо помилування.

Вважаємо, що відповідна градація може бути проведена таким чином: 1) засуджена до довічного позбавлення волі особа має право подати клопотання про помилування після відбуття нею не менше двадцяти років призначеного покарання у разі засудження за умисне вбивство з кваліфікуючими ознаками, окрім умисного вбивства двох або більше осіб; малолітньої дитини або жінки, яка завідомо для винного перебувала у стані вагітності; вчиненого 3 особливою жорстокістю; вчиненого особою, яка раніше вчинила умисне вбивство, за винятком вбивства, передбаченого статтями 116-118 цього Кодексу; 2) для осіб, які вчинили умисне вбивство двох або більше осіб; малолітньої дитини або жінки, яка завідомо для винного перебувала у стані вагітності; вчиненого 3 особливою жорстокістю; вчиненого особою, яка раніше вчинила умисне вбивство, за винятком вбивства, передбаченого статтями 116-118 цього Кодексу, і були засуджені до довічного позбавлення волі, такий строк має становити не менше 30 років.

Варто зазначити, що не слід буквально прив'язуватися до кваліфікації дій винного, наприклад, за ст. 115 КК. Адже кримінальна відповідальність за умисне заподіяння смерті передбачена не лише цією нормою. Якщо винний умисно вб'є декількох працівників поліції, його дії можуть бути оцінені юри- дично за ст. 348 КК. Проте смерть кількох осіб повинна бути перешкодою для застосування більш короткого терміну звернення про помилування.

У разі звільнення від покарання із закінченням строків давності виконання обвинувального вироку законодавець більш вдало сконструював текст закону порівняно з аналогічною підставою для інституту звільнення від кримінальної відповідальності (ст. 49 та 80 КК). Однією з кардинальних відмінностей є врахування розміру призначеного покарання, а не розміру покарання, визначеного санкцією статті КК. Очевидно, що така відмінність є обгрунтованою і доцільною. Тож такий підхід дістає позитивні відгуки науковців [12, с. 326].

Якщо засуджений ухиляється від виконання вироку, строки давності, передбачені пунктами 1-3 частини першої ст. 80 КК, подвоюються. У цій частині строки, передбачені пунктами з першого по третій, становлять два-три-п'ять років відповідно. Пункт четвертий-п'ятий передбачають відповідно десять і п’ятнадцять років давності. Фактично подвоєння строків є більш несприятливим для тих, хто вчинив менш тяжкі чи небезпечні злочини. Ухилення ж для більш небезпечних злочинців наслідками подвоєння строків не загрожує.

Наприклад, за вчинення грабежу за попередньою змовою групою осіб суд може призначити одному зі співучасників 4 роки позбавлення волі з огляду на його суспільну небезпеку. Отже, строки давності згідно 3 п. 3 ч. 1 ст. 80 КК становитимуть 5 років. Іншому співучаснику може бути призначене більше покарання за такий же злочин, наприклад 6 років, і тоді строки давності становитимуть 10 років. Якщо обидва цих злочинців будуть ухилятися, строки давності для них зрівняються. Для менш небезпечного співучасника вони подвояться, для більш небезпечного - залишаться тими ж, якими й були. Фактично у цьому аспекті між ними виникне знак рівності, строк давності для кожного з них становитиме 10 років.

Окрім загальної несправедливості такої норми, необхідно відзначити і відсутність диференціюючого впливу ухилення від виконання вироку на кримінально-правові наслідки для осіб, які вчинили окремі тяжкі чи особливо тяжкі злочини.

Чітко простежується намагання законодавця диференціювати кримінальну відповідальність осіб, які вчинили корупційні злочини. Несистемність цього процесу рівною мірою знайшла своє відображення і в інституті звільнення від покарання. Враховуючи різний ступінь тяжкості так званих 
корупційних злочинів, практично однаковий їх вплив на неможливість бути звільненим від покарання не надто відповідає принципу справедливості.

Останній аспект засобу диференціації, що досліджується, - це встановлення диференціюючого значення положень ст. 77 КК, які допускають призначення додаткового покарання у разі звільнення від відбування основного покарання 3 випробуванням. Фактично законодавець створює умови для забезпечення різноманітності часткового впливу окремої форми реалізації кримінальної відповідальності на особу, проте в істотно вужчих межах, ніж тоді, коли 6 засуджений відбував основне покарання. Це дозволяе більш тонко індивідуалізувати кримінальну відповідальність судом. Варто зауважити, що в науковій літературі загалом позитивно оцінюють такий підхід законодавця [13, с. 12; 14, с. 294; 15, с. 187], проте є і протилежні міркування [16, с. 186].

Ми ж вважаємо, що в сучасних умовах, коли звільнення від покарання з випробуванням активно застосовується 3 найбільшою питомою вагою серед інших підстав звільнення, в умовах незбалансованості санкцій статей Особливої частини КК і збереження можливості застосування до засудженого додаткових покарань сприяє диференційованому підходу до кримінальної відповідальності i, як наслідок, реалізації завдань кримінального закону, а також забезпеченню справедливості. У цьому контексті хочемо зауважити, що ст. 75 КК не передбачає звільнення особи від відбування додаткового покарання, призначеного судом, а лише від того основного покарання, яке прямо вказане у тексті ч. 1 ст. 75 КК. Тому в цій частині ми цілком солідарні із О. П. Горохом, який вважає звільнення засудженого від відбування додаткового покарання неправильним застосуванням кримінального закону [17, с. 676].

\section{Висновки}

Не всі підстави звільнення від покарання чи його відбування мають значення для диференціації кримінальної відповідальності. Окремі 3 них сконструйовані законодавцем таким чином, що фактично характеризують диференціацію кримінально-правового впливу, як-от звільнення від покарання за хворобою для осіб, які стали неосудними під час відбування покарання. Також у чинному КК фактично відсутне диференціююче значення інститутів амністії та помилування через недостатнє нормативне урегулювання останніх у КК. Варіативність у застосуванні амністії, згідно з положеннями ст. 4 Закону України
«Про застосування амністії в Україні», додатково свідчить на користь цього висновку. Адже кримінально-правові наслідки діяння повинні визначатися виключно КК.

Звільнення засудженого від відбування основного покарання 3 випробуванням 31 збереженням застосування призначених судом додаткових покарань дозволяє розширити можливі варіанти застосування цього інституту для кращої реалізації принципу справедливості. Тому положення ст. 77 КК забезпечують диференціацію кримінальної відповідальності та більш точний і персоналізований підхід у застосуванні заходів кримінальної відповідальності до особи судом.

\section{Список використаних джерел:}

1. Хавронюк М. І. Диференціація кримінальної відповідальності або чи не очікує Україну соціальна катастрофа? Кримінальний кодекс України 2001 р.: проблеми застосування і перспективи удосконалення : матеріали Міжнародного симпозіуму 11-12 вересня 2009 року. Львів: ЛьвДУВС 2009. C. $147-151$.

2. Грищук В. К. Поняття диференціації кримінальної відповідальності. Кримінальний кодекс Украӥни 2001 р.: проблеми застосування $i$ перспективи удосконалення : матеріали Міжнародного симпозіуму 11-12 вересня 2009 року. Львів: ЛьвДУВС, 2009. С. 40-43

3. Орловская Н. А. Уголовно-правовые санкции: проблемы определения, классификации и функционального анализа. Одесса: Юридична література, 2010. 296 с.

4. Лесниевски-Костарева Т. А. Дифференциация уголовной ответственности. Теория и законодательная практика. Москва : Норма, 1998. C. 126

5. Дудоров О. О. Кримінальна відповідальність: окремі дискусійні аспекти. Актуальні проблеми кримінальної відповідальності : матеріали міжнар. наук.-практ. конф., 10-11 жовт. 2013 р. Харків : Право, 2013. С. 848

6. Горох О. П. Звільнення від покарання та його відбування (аналіз судової статистики). Наука і правоохорона. 2016. № 3. С. 167-175.

7. Постанова колегії суддів Другої судової палати Касаційного кримінального суду від 11 червня 2019 року. Справа № 536/1367/17. URL: http://www.reyestr.court.gov.ua/Review/ 82541248 (дата звернення: 11.03.2020).

8. Постанова колегії суддів Першої судової палати Касаційного кримінального суду від 5 лютого 2019 року. Справа № 335/7300/16-к. URL: http://www.reyestr.court.gov.ua/Review/ 79880110 (дата звернення: 11.03.2020).

9. Кругликов Л. Л., Васильевский А. В. Дифференциация ответственности в уголовном праве. СПб.: Издательство «Юридический центр Пресс», 2002. C. 163

10. Про внесення змін до Закону України «Про застосування амністії в Україні» щодо повної 
реабілітації політичних в'язнів : Закон України від 27 лютого 2014 року. URL: https://zakon.rada.gov. ua/laws/show/792-18 (дата звернення: 11.03.2020).

11. Рішення ЄСПЛ у справі «Петухов проти України (№ 2)» (Заява № 41216/13). URL: https://zakon.rada.gov.ua/laws/show/974 d98 (дата звернення: 12.03.2020).

12. Письменський Є. О. Закінчення строків давності виконання обвинувального вироку як підстава для звільнення особи від відбування покарання. Науковий вісник Львівського державного університету внутрішніх справ. 2011. № 1. С. 320-328

13. Книженко О. О. Звільнення від відбування покарання з випробуванням за кримінальним правом України : автореф. дис. ... канд. юрид. наук: 12.00.08. Харків, 2003. 20 с

14. Шиян Д. Проблема застосування додаткових покарань у разі звільнення від відбування основного покарання 3 випробуванням. Вісник Наиіонального університету «Львівська політехніка». Серія «Юридичні науки». Львів : Видавництво Львівської політехніки, 2017. № 876 . C. $290-295$.

15. Богатирьова О. І., Олефір Л. І. Пробація або звільнення від відбування покарання з випробуванням як форма кримінальної відповідальності. Актуальні проблеми вітчизняної юриспрудениії. Спеивипуск. 2017. № 1. С. 185-188.

16. Філонов В., Назимко Є. Реформування інституту звільнення від відбування покарання з випробуванням у світлі сучасних тенденцій гуманізації пенальної політики України. Право України. 2010. № 3. С. 184-189.

17. Горох О. П. Сучасні кримінально-правові проблеми звільнення від покарання та його відбування. Київ: Дакор, 2019. 676 с.

Legal institutions of exemption from punishment or from serving sentencing, prescribe broad jurisdictions of judges. It means that they can't apply this form of criminal responsibility to those found guilty under the court's sentence. But this wide judicial discretion is regulated by the Criminal Code of Ukraine. The legislator has also envisaged different conditions and grounds for exemption from punishment or from serving sentencing. That's why the question about differentiating role of these legal institutions appears. Moreover, giving positive answer on abovementioned question, another problem occurs. It will be necessary to find out which of the norms, regulating grounds for exemption from punishment or from serving sentencing, provide variable influence of norms of criminal law.

In this research, we plan to explain importance of legal institutions of exemption from punishment or from serving sentencing concerning differentiation of criminal responsibility. The goal is to define peculiarities of all the grounds of exemption from punishment or from serving sentencing taking and their differentiating possibilities.

As the result of this study, it was suggested that part of grounds of exemption from punishment or from serving sentencing doesn't provide any variability of criminal responsibility. Legislator regulated some of them in the specific way. They actually represent differentiation of legal influence (not responsibility). For instance: exemption from punishment in cases of insanity in the process of serving sentencing. Moreover, institutions of amnesty and pardon actually lack any differentiating functions due to inadequate normative regulation in the Criminal Code of Ukraine.

Exemption of the convicted person from serving sentencing of main punishment, but with the obligation of serving supplemental punishments allows the court to widen possible variations of application of this institute. This helps principle of justice to be implemented. That's why, provisions of article 77 of the Criminal Code provide differentiation of criminal responsibility and more accurate and individualized approach in application of means of criminal responsibility to guilty person.

Key words: differentiating role, punishment, amnesty, pardon application, supplemental punishment. 